\title{
Margaret McCartney: Fat doctors are patients too
}

\author{
Margaret McCartney general practitioner, Glasgow
}

The new Belgian health minister, Maggie De Block, is a former GP. She also reportedly weighs 20 stone $(127 \mathrm{~kg})$, prompting critics to claim that she is unsuitable to manage a portfolio that includes reducing obesity.

Recently, England's chief medical officer, Sally Davies, said that she was "perpetually surprised" at how many NHS staff were overweight. "How are they to have the impact on patients if they are not thinking about it for themselves?" she asked. ${ }^{1}$ Meanwhile, Simon Stevens, chief executive of NHS England, has told staff to join gyms and weight loss clubs, to "fight against obesity." 2

The message for doctors is clear: don't be fat. But obesity is complicated. It is closely related to mental distress, ${ }^{3}$ including depression. ${ }^{4}$ Unlike drinking excessive alcohol, smoking, drug misuse, or unprotected sex, this "unhealthy" predilection is hard to hide.

Overweight and pregnant women talk of stigma and of "humiliation" during antenatal care. ${ }^{5}$ Patients feel shame and a reluctance to talk about their weight, despite a strong sense of personal responsibility. ${ }^{6}$ And almost a quarter of nurses in a North American study said that they were repulsed by caring for obese patients.

Healthcare staff are patients too. We professionals, who deal daily with the consequences of obesity, have weight problems ourselves; knowledge doesn't make us immune. Much has been made of US studies purporting to show that patients trust fat doctors' advice less: but these were theoretical studies ${ }^{8}$ that did not examine patients in long term relationships with their own GPs.

The NHS can be a toxic environment. Shift working is a risk factor for obesity, ${ }^{9}$ and less than a third of doctors working them manage regular meals. ${ }^{10}$ Meanwhile, fast food franchises selling energy dense foods have gained a firm foothold in NHS hospitals. ${ }^{11}$

Weight loss interventions in primary care yield clinically insignificant reductions in weight ${ }^{12}$; but, of people invited to typical non-NHS weight loss programmes, only $1 \%$ have sustained their goal weight after five years. ${ }^{13}$

It would be better to concentrate on healthy work environments. The NHS should promote the health benefits of cycling, by committing to having most employees cycle to work, promoting safe cycle lanes, and ensuring bike storage and shower facilities. $^{14}$

We should not assume that fat doctors are bad doctors or are "not thinking about it." Those of us who have gained, lost, gained, lost, and gained weight again are only too aware of our failings. The medical profession should be tolerant of these- the same problems that our other patients face.

Competing interests: I have read and understood the BMJ policy on declaration of interests and declare the following interests: I'm an NHS GP partner, with income partly dependent on Quality and Outcomes Framework points. I'm a part time undergraduate tutor at the University of Glasgow. l've written a book and earned from broadcast and written freelance journalism. I'm an unpaid patron of Healthwatch. I make a monthly donation to Keep Our NHS Public. I'm a member of Medact. I'm occasionally paid for time, travel, and accommodation to give talks or have locum fees paid to allow me to give talks but never for any drug or public relations company. I was elected to the national council of the Royal College of General Practitioners in 2013.

Follow Margaret McCartney on Twitter, @mgtmccartney

1 Millett D. Exclusive: GPs should not be fat, says CMO Dame Sally Davies. GP 23 May 2014. www.gponline.com/exclusive-gps-not-fat-says-cmo-dame-sally-davies/article/ 1295549.

2 Helm T. NHS chief urges hospital staff to join gyms in anti-obesity fight. Guardian 18 Oct 2014. www.theguardian.com/society/2014/oct/18/hospital-staff-urged-to-set-exampleobesity-fight.

3 Gariepy G, Nitka D, Schmitz N. The association between obesity and anxiety disorders in the population: a systematic review and meta-analysis. Int $J$ Obes 2010;34:407-19.

4 Luppino FS, de Wit LM, Bouvy PF, Stijnen T, Cuijpers P, Penninx BW, et al. Overweight, obesity and depression: a systematic review and meta-analysis of longitudinal studies. Arch Gen Psychiatry 2010;67:220-9.

5 Puhil RM, Heuer CA. The stigma of obesity: a review and update. Obesity 2009;17:941-64. Brown I, Thompson J, Tod A, Jones G. Primary care support for talking obesity: a qualitative study of the perceptions of obese patients. Br J Gen Pract 2006;56:666-72.

7 Furber CM, McGowan L. A qualitative study of the experiences of women who are obese and pregnant in the UK. Midwifery 2011;27:437-44.

8 Puhl RM, Gold JA, Luedicke J, DePierre JA. The effect of physicians' body weight on patient attitudes: the implications for physician selection, trust and adherence to medical advice. Int J Obes 2013;37:1415-21.

9 Amani R, Gill T. Shiftworking, nutrition and obesity: implications for workforce health-a systematic review. Asia Pac J Clin Nutr 2013;22:698-708.

10 Jackson EJ, Moreton A. Safety during night shifts: a cross-sectional survey of junior doctors' preparation and practice. BMJ Open 2013;3:e003567.

11 Donnelly L, Shields R, Waddell L. NHS hospital cafes "are helping to fuel the obesity crisis." 2 Aug 2014. www.telegraph.co.uk/health/healthnews/11006903/NHS-hospitalcafes-are-helping-to-fuel-the-obesity-crisis.html.

12 Booth HP, Prevost TA, Wright A, Gulliford MC. Effectiveness of behavioural weight loss interventions delivered in a primary care setting: a systematic review and meta-analysis. Fam Pract 8 Oct 2014, doi:10.1093/fampra/cmu064.

13 Henegan C, blog. The men who made us thin: the evidence. 14 Aug 2013. www. carlheneghan.com/2013/487/the-men-who-made-us-thin-the-evidence/. 
14 Flint E. Associations between active commuting, body fat, and body mass index: population based, cross sectional study in the United Kingdom. BMJ 2014;349:g4887.

Cite this as: BMJ 2014;349:g6464

C BMJ Publishing Group Ltd 2014 